\title{
MINERALOGICAL AND MORPHOLOGICAL CHARACTERIZATION OF ORGANICALLY AMENDED SOIL
}

\author{
R. Suya Padhra Haridha ${ }^{1,2, 凶}$, F. Jeyamangalam ${ }^{3}$, R. Mary Jenila ${ }^{1}$ \\ and S. C. Vella Durai ${ }^{4}$ \\ ${ }^{1}$ Department of Physics, St. Xavier's College (Autonomous), \\ Palayamkottai-627 002, Tamil Nadu, India \\ ${ }^{2}$ Department of Physics, A.P.C. Mahalaxmi College for Women, \\ Thoothukudi-628 002, Tamil Nadu, India. \\ ${ }^{3}$ Department of Physics, Sarah Tucker College (Autonomous), \\ Tirunelveli-627 007, Tamil Nadu, India. \\ ${ }^{4}$ Department of Physics, JP College of Arts and Science, Agarakattu, \\ Tenkasi-627 852, Tamil Nadu, India. \\ (Affiliated to Manonmaniam Sundaranar University, Tirunelveli-627012, India.) \\ ${ }^{\otimes}$ Corresponding Author: suyatweety31@gmail.com
}

\begin{abstract}
The objective of this paper is to propose a soil characterization methodology based on mineralogical and morphological analyses. This paper intends to offer the consequences of Powder X-ray diffraction (PXRD) exams and scanning electron microscopy-Energy dispersive X-ray spectroscopy (SEM-EDS) analyses which predict the presence of minerals in organically treated soil. PXRD offers records on the crystal shape of the pattern and different structural parameters. The observed PXRD patterns indicate the presence of Quartz, Kaolinite and Calcite. The FTIR study also confirms the variation in minerals before and after the application of the organic amendments. FTIR offers the molecular decision of mineral and natural purposeful corporations of soil. SEM exams had been extensively utilized to assess microstructural modifications within the tested specimens and examine the effects of pore size in the sandy soil. The results of SEM indicate the improvement in soil structure with a good Water Holding Capacity (WHC). EDAX studies confirm the significant variation in micronutrients. Measurement of $\mathrm{pH}$ and electric conductivity (EC) parameters offers valuable records for assessing soil situation for plant growth, nutrient cycling and organic hobby. It also improves the macro-nutrients like Nitrogen (N), Phosphorus( $\mathrm{P}$ ) and Potassium (K).
\end{abstract}

Keywords: EDAX, FTIR, Mineralogical Analyses, Organic Amendment, PXRD, SEM.

RASĀYAN J. Chem., Vol. 14, No.4, 2021

\section{INTRODUCTION}

Our country is predominantly vegetarian and pulses play an important role in Indian agriculture. Pulses are the main source of protein and amino acids. In India, the total production of pulses for the last decades was around 13 to 15 million metric tons. Black gram (Vigna Mungo L) is one of the major pulse crops among the grain legume grown in India. It is commonly known as "Urad" or "Urad bean". Black gram is a very nutrient-demanding crop that needs organic or inorganic fertilizers to promote crop yield. ${ }^{1}$ It is more nutritious, containing one-third of the protein in it and nourished with Phosphorus, Potassium, Calcium along a notable amount of Sodium. It is also reported that it is substantially good in Vitamin A, $\mathrm{B}_{1}, \mathrm{~B}_{3}$ other than proteins. ${ }^{2}$ Nutrients that are removed from the soil can be retrieved with the usage of fertilizers and it also acts as an additive for the soil to enhance the yield. ${ }^{3,4}$ Organic Farming, a system that favors the use of organic materials such as manure to improve the health of the soil and to improve the yield. ${ }^{5}$ Soil fertility and productivity can be enhanced with the addition of animal manures and crop residues. Organic amendments are said to improve soil structure, texture and increase biochemical activities of soil microorganisms aside from adding essential nutrients to the soil. ${ }^{6}$ It also avoids the use of synthetic fertilizers and pesticides thereby reducing their deleterious effect on the environment. Organic agriculture is healthier not only for humans and animals but also for the environment. The continuous Rasayan J. Chem., 14(4), 2255-2262(2021) 
cultivation of soil gradually decreases the yield due to the depletion of organic matter which is known to be a reservoir of plant nutrients. ${ }^{7}$ The quality of the soil depicts the potentiality to support the production. ${ }^{8}$ Goat manure $(\mathrm{G})$ will produce healthier plants and higher crop yields and it is suitable for all kinds of plants. Vermicompost (VC) contains microsites rich in available carbon and nitrogen. Adding compost specifically to the sandy soils as a supplement makes it a valuable one. Swine manure (SM) is a good source of nutrients; particularly manure is a good source of nutrients, mainly for vegetables. Most studies on the implementation of organic manure have been focused on crop yield responses. Soil electrical conductivity (EC) mapping is proposed as a cheaper cum precision tool for farmers to undertake and characterize soil inside their farm fields similar to the $\mathrm{pH}$ profile of the soil. Soil $\mathrm{pH}$ barely will increase with soil intensity due to the accumulation of simple cation in cultivated lands. Nitrogen is the maximum critical detail acquired through plants from the soil. About $80 \%$ of the environment is nitrogen gas. Nitrogen has an impact on the pleasantness of plant culmination and it will increase the fruit protein content material. Phosphorus is a crucial plant nutrient vital for root development. Phosphorus is the second major detail for plant growth. It is an indispensable part of adenosine di-phosphate and adenosine tri-phosphate. The overall potassium in soil is pretty massive, incredibly small quantities are to be had for plant growth. FTIR spectroscopy is strongly appropriate for characterizing natural rely on the sandy soil pattern. This spectroscopy is normally utilized in soil quantitative evaluation. In the above subject matter lay the estimation of modifying soil physical properties with and without natural manure. The current study emphasizes the physical properties of the soil which can be used as an index for performing the analysis of the quality of the soil and also encompasses the mineralogical findings of the organic manure treated soil and untreated soil through sophisticated techniques.

\section{Site Description}

This study was conducted at Servaikaranmadam, Thoothukudi district of Tamilnadu. The experimental farm is situated at $8.6970^{\circ} \mathrm{N}$ latitude and $78.0502^{\circ} \mathrm{E}$ longitude. Soil samples from the depth of about $0-30$ $\mathrm{cm}$ were collected from the study area for soil analysis and pot experiment. The soil samples were randomly picked up from the study area and it was initially dried in air for 14 hours and then it was sieved to pass through an $8 \mathrm{~mm}$ sieve. The sample was grounded and sieved through $2 \mathrm{~mm}$ sieve for physical and chemical characterization of the soil. The experimental area was split up into plots with an area of $40 \mathrm{~m}^{2}$, the distance between the plants is $10 \mathrm{~cm}$ and the distance between the rows is $30 \mathrm{~cm}$.

\section{Material and Methods}

\section{EXPERIMENTAL}

The treatments were laid out in Randomized Block Design (RBD) with three repetitions. The field consists of five treatments comprising G of $12.5\left(\mathrm{t} \mathrm{ha}^{-1}\right)$, SM of $12.5\left(\mathrm{t} \mathrm{ha} \mathrm{C}^{-1}\right), \mathrm{VC}$ of $12.5\left(\mathrm{t} \mathrm{ha} \mathrm{h}^{-1}\right)$, $\mathrm{G}+\mathrm{SM}+\mathrm{VC}$ of $12.5\left(\mathrm{t} \mathrm{ha}^{-1}\right)$ and a Control plot. The above-mentioned organic manures were applied and left for about 30 days for drip irrigation. After 30 days Black gram (Vigna Mungo L) seeds were sown. The variety chosen for the cultivation was Vamban BG (4). The irrigation was preceded according to the proposed design throughout the growing season. The experimental site was kept free from weeds by eradicating them manually, whenever it was observed in it. The harvesting was done in about 90 days. The soil samples were collected again, sieved and kept in zip lock covers for further investigations. ${ }^{9}$ Figure-1 shows the field area of the present work. The soil samples were examined for soil $\mathrm{pH}$, Electrical Conductivity (EC), Nitrogen (N), Phosphorus (P), Potassium (K), Organic Carbon (OC) and Organic matter $(\mathrm{OM}) .{ }^{10}$ The potentiometry method (1:2.5 - soil: water) was followed to determine the values of $\mathrm{pH}$ and EC of the soil samples. Nitrogen, Phosphorus and Potassium content were measured. Organic carbon was measured using the Walkey and Black method. The estimation of mineralogical composition and various functional groups present in the soil were determined using the FTIR and PXRD methods. On the other hand, soil morphology and elemental analysis have been done using SEM with EDAX techniques.

\section{Soil Analysis}

The top soil sample was collected from the field area before the commencement of any trials. Samples have also been taken 30 days after manure application and also after harvesting the yield of the crop period of about 90 days. It was dried in air and sieved through $2 \mathrm{~mm}$ sieve.

ORGANICALLY AMENDED SOIL 
RASĀYAN J. Chem.

Vol. 14 | No. 4 |2255-2262| October- December | 2021

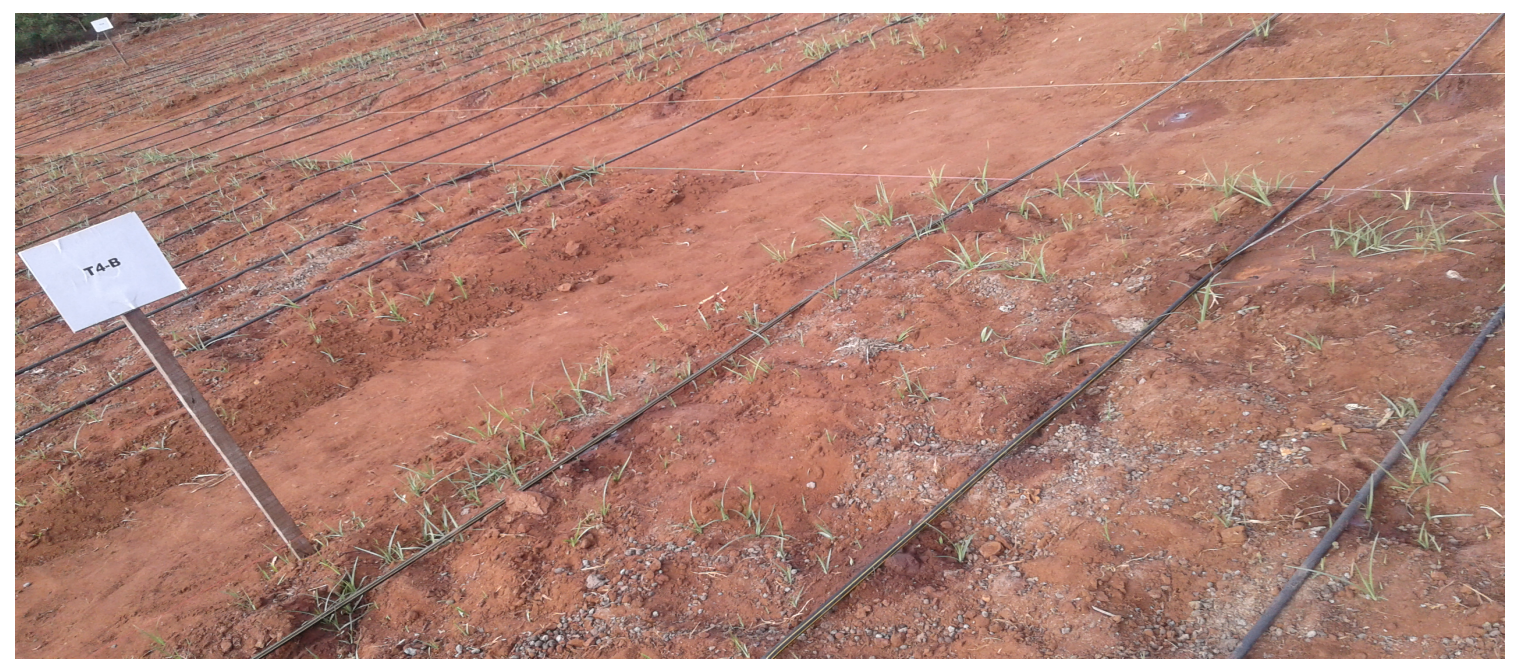

Fig.-1: Field Area Used for the Study

Mineralogical and Morphological Analysis of Soil Samples

The nature of the intake of soil, identification of its mineralogical composition and different kinds of functional groups present in it was carried out by the FTIR method. The wavelength region chosen for mineralogical study is $400-4000 \mathrm{~cm}^{-1}$ which is the mid Infra-Red region. The pressed pellet made of $\mathrm{kBr}$ was used to record the spectrum. Scanning Electron Microscopy of JEOL JSM 6390 model is used to determine the morphological characteristics of the soil samples. Energy Dispersive X-ray Spectroscopy (EDAX) along with SEM gives the details of the chemical composition of the sample.

\section{RESULTS AND DISCUSSION}

\section{Physico-Chemical and Chemical Properties}

The soil samples were analyzed for determining the physicochemical properties. In the present study, the $\mathrm{pH}$ and EC value were lowest for VC @ $12.5 \mathrm{t} \mathrm{ha}^{-1}$. Nitrogen content rate also seems to be maximum for the same concentration of about $156 \mathrm{~kg} \mathrm{ha}^{-1}$ than the control of $103.8 \mathrm{~kg} \mathrm{ha}^{-1}$. The value of phosphorus and potassium was high for G+SM+VC@12.5 $\mathrm{t} \mathrm{ha}^{-1}$. As the rate of swine manure is increased there is a significant variation in the value of $\mathrm{pH}$. The cause of this variation may be due to the improvement in microbial activity. It happens due to the decomposition process which leads to the liberation of cations like $\mathrm{Ca}, \mathrm{Mg}, \mathrm{Na}$ and organic matter during mineralization. The physicochemical properties of the soil samples (Before Harvest) were displayed in Table-1.

Table-1: Physico-Chemical and Chemical Properties of the Soil Samples (Before Harvest)

\begin{tabular}{|c|c|c|c|c|c|c|c|}
\hline \multirow[t]{2}{*}{ S. No. } & \multirow[t]{2}{*}{ Manure } & \multirow{2}{*}{$\begin{array}{c}\text { Dose } \\
\left(\mathrm{t} \mathrm{ha}^{-1)}\right.\end{array}$} & \multirow[t]{2}{*}{$\mathrm{pH}$} & \multirow{2}{*}{$\begin{array}{c}\text { Electrical } \\
\text { Conductivity } \\
\left(\mathrm{ds} \mathrm{m}^{-1}\right)\end{array}$} & \multicolumn{3}{|c|}{ Macronutrients } \\
\hline & & & & & $\begin{array}{l}\text { Nitrogen } \\
\left(\mathrm{kg} \mathrm{ha}^{-1}\right)\end{array}$ & $\begin{array}{l}\text { Phosphorus } \\
\left(\mathrm{kg} \mathrm{ha}^{-1}\right)\end{array}$ & $\begin{array}{l}\text { Potassium } \\
\left(\mathrm{kg} \mathrm{ha}^{-1}\right)\end{array}$ \\
\hline 1 & Goat manure $(\mathrm{G})$ & 12.5 & 7.2 & 1.5 & 103.7 & 12.3 & 647.4 \\
\hline 2 & Swine Manure(SM) & 12.5 & 7.5 & 1.1 & 138.3 & 12.3 & 753.6 \\
\hline 3 & Vermicompost(VC) & 12.5 & 7.3 & 1.0 & 155.6 & 12.3 & 491.7 \\
\hline 4 & $\mathrm{G}+\mathrm{SM}+\mathrm{VC}$ & 12.5 & 7.1 & 0.5 & 140.8 & 42.0 & 958.7 \\
\hline 5 & Control & - & 7.6 & 1.5 & 86.4 & 7.4 & 368.1 \\
\hline
\end{tabular}

\section{PXRD Characterization}

To identify the minerals present in the soil samples it was exposed to Powder X-ray Diffraction Analysis. The XPERT- PRO Diffractometer system with PW3050/60 type goniometer was used for the analysis. The setting of the generator is $30 \mathrm{~mA} / 40 \mathrm{kV}$ with $\mathrm{CuK} \alpha$ radiation of $\lambda=1.54060 \mathrm{~A}^{0}$. A continuous scanning process was carried out with the start position (2q) from 10 to end position (2q) 80 with the step size of $0.017 \mathrm{sec}$ and step time of $3.23 \mathrm{sec}$. The samples are analyzed for the PXRD patterns ${ }^{11}$ and the $2 \theta$ values are compared with the standard values of JCPDS data. Experimental ' $2 \theta$ ' values along with the standard values referred to in JCPDS are mentioned in table.-2 and 3. The observed PXRD patterns of 
RASĀYAN J. Chem.

Vol. 14 | No. 4 |2255-2262| October-December | 2021

untreated soil results indicate the presence of silicate minerals like Quartz, clay minerals such as Montmorillonite, then Illite, Hematite and Aragonite. The presence of these minerals accounts for the low activity clay and nutrient depletion. ${ }^{12}$ Figure-2 and 3 display the PXRD spectrum of untreated and treated soil.

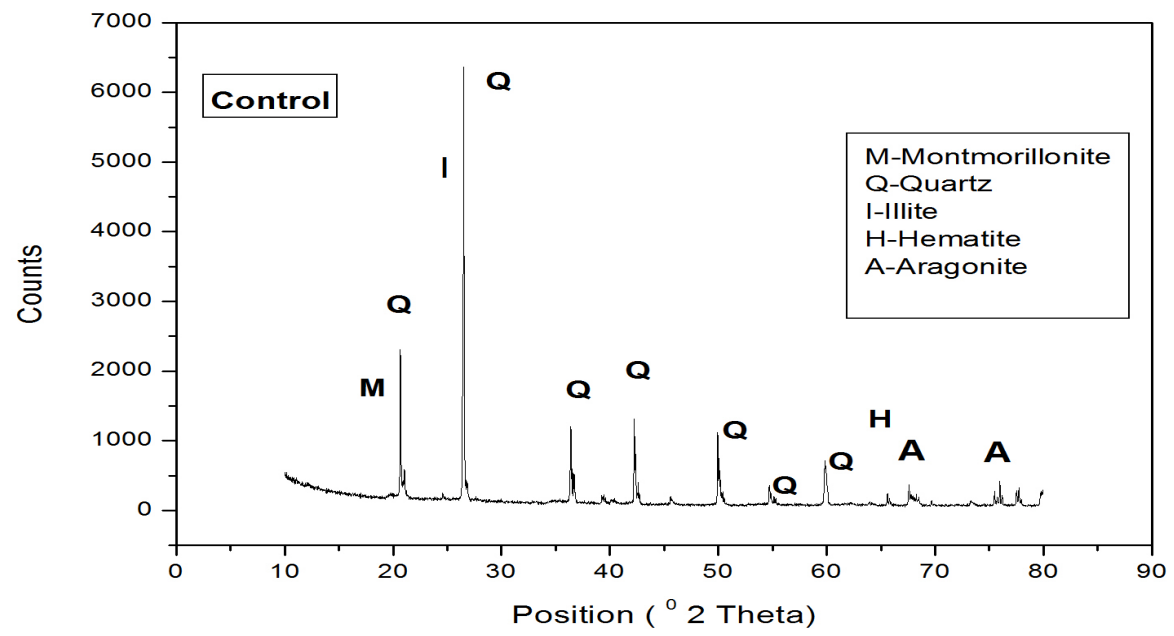

Fig.-2: PXRD Pattern for Control Plot

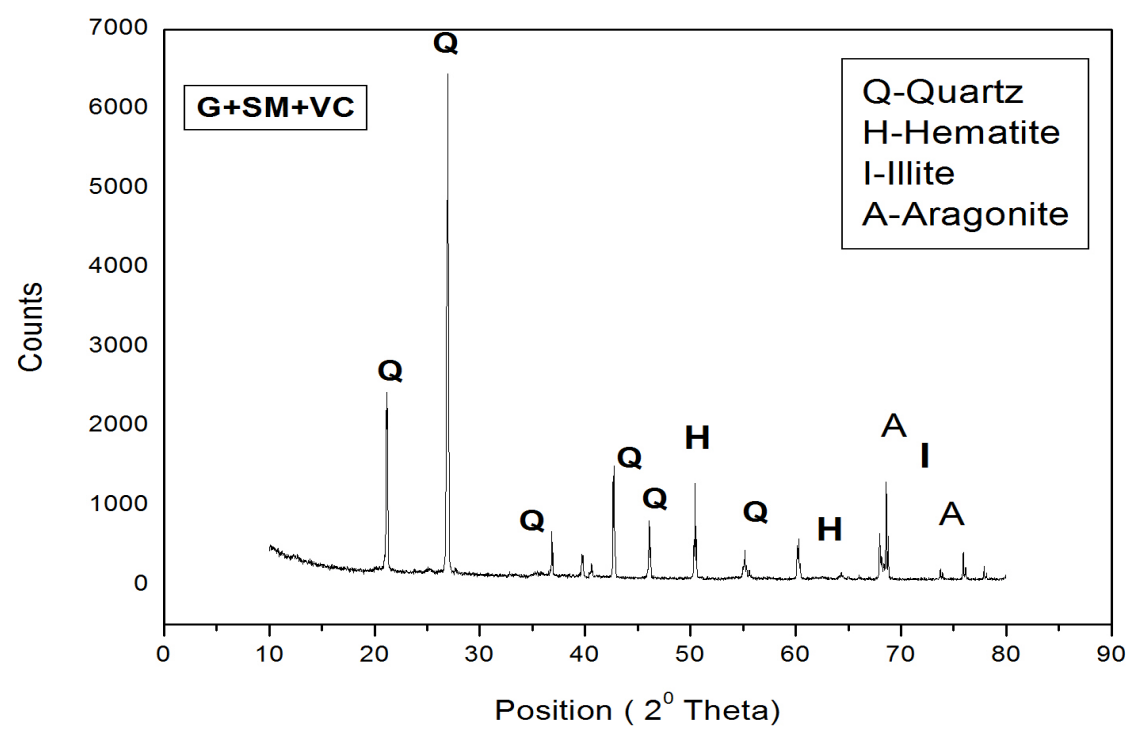

\section{FTIR Characterization}

Fig.-3: PXRD Pattern for G+VC+SM Plot

Figure-4 depicts the FTIR spectrum of the untreated soil. The Si-O stretching vibration were seems to be at $469.26 \mathrm{~cm}^{-1}, 779.36 \mathrm{~cm}^{-1}, 796.56 \mathrm{~cm}^{-1}, 913.97 \mathrm{~cm}^{-1}, 1008.60 \mathrm{~cm}^{-1}, 1878.63 \mathrm{~cm}^{-1}$ indicates the existence of silicate mineral-like Quartz ${ }^{13}$. Band occurs at $3699 \mathrm{~cm}^{-1}$ and $3623 \mathrm{~cm}^{-1}$ specify the presence of the hydroxyl group $(-\mathrm{OH})$, it is accounted for the stretching vibration of inner surface $\mathrm{OHs}$ and $\mathrm{OH}$ respectively. These features represent the presence of clay minerals like kaolinite in the soil sample. Bands around $1035 \mathrm{~cm}^{-1}$ and $432 \mathrm{~cm}^{-1}$ also indicate the presence of kaolinite. ${ }^{14}$ The vibration attains at $694.40 \mathrm{~cm}^{-1}$ accounts for the presence of calcite. In the interlayer region of montmorillonite, there is the presence of water molecules, in which stretching of $\mathrm{H}-\mathrm{O}-\mathrm{H}$ has occurred at $3400 \mathrm{~cm}^{-1}$. It is an expansive clay mineral when exposed to moisture that causes excessive swelling and during drying undergoes excess shrinkage. The wavenumber from $2925 \mathrm{~cm}^{-1}$ to $2850 \mathrm{~cm}^{-1}$ is due to $\mathrm{C}-\mathrm{H}$ stretching which supports 
RASĀYAN J. Chem.

Vol. 14 | No. 4 |2255-2262 | October- December | 2021

the presence of organic carbon content in the soil which is treated with organic manure. ${ }^{15}$ The FTIR spectrum of the soil treated with organic manure is shown in Fig.-5.

Table-2: Identified Minerals from the Control Plot

Control Plot

\begin{tabular}{c|c|c|c|c|c}
\hline $\begin{array}{c}\text { Observed } \\
2 \theta\end{array}$ & $\begin{array}{c}\text { Standard } \\
2 \theta\end{array}$ & hkl & Identified Mineral & System & JCPDS \\
\hline 19.7 & 19.7 & 100 & Montmorillonite-15A & Hexagonal & $29-1498$ \\
\hline 20.6 & 20.9 & 100 & Quartz & Hexagonal & $85-1780$ \\
\hline 24.5 & 24.2 & 112 & Illite & Monoclinic & $29-1496$ \\
\hline 26.5 & 26.5 & 001 & Quartz & Hexagonal & $85-1780$ \\
\hline 36.6 & 36.6 & 110 & Quartz & Hexagonal & $85-1053$ \\
\hline 39.4 & 39.4 & 102 & Quartz & Hexagonal & $85-1053$ \\
\hline 42.3 & 42.5 & 200 & Quartz & Hexagonal & $85-0865$ \\
\hline 50.0 & 50.0 & 112 & Quartz & Hexagonal & $85-0865$ \\
\hline 54.7 & 54.2 & 0013 & Montmorillonite-22A & Hexagonal & $29-1499$ \\
\hline 65.5 & 65.1 & 125 & Hematite & Hexagonal & $85-1054$ \\
\hline 67.5 & 67.9 & 104 & Aragonite & Orthorhombic & $76-0606$ \\
\hline 68.4 & 68.6 & 242 & Aragonite & Orthorhombic & $76-0606$ \\
\hline
\end{tabular}

Table-3: Identified Minerals from the G+SM+VC Plot

\begin{tabular}{c|c|l|c|c|c}
\hline \multicolumn{7}{c|}{ G+SM+VC Plot } \\
\hline $\begin{array}{c}\text { Observed } \\
2 \theta\end{array}$ & $\begin{array}{c}\text { Standard } \\
2 \theta\end{array}$ & hkl & Identified Mineral & System & JCPDS \\
\hline 10.1 & 10.5 & 021 & Kaolinite & Anorthic & $02-0105$ \\
\hline 21.0 & 21.6 & 021 & Illite & Monoclinic & $29-1496$ \\
\hline 25.1 & 25.9 & 111 & Kaolinite & Monoclinic & $89-6538$ \\
\hline 26.8 & 26.5 & 001 & Quartz & Hexagonal & $85-1780$ \\
\hline 36.8 & 36.6 & 110 & Quartz & Hexagonal & $85-1053$ \\
\hline 39.6 & 39.5 & 102 & Quartz & Hexagonal & $85-0594$ \\
\hline 40.6 & 40.3 & 202 & Hematite & Hexagonal & $88-2359$ \\
\hline 42.6 & 42.5 & 200 & Quartz & Hexagonal & $85-0865$ \\
\hline 46.0 & 45.9 & 201 & Quartz & Hexagonal & $85-0865$ \\
\hline 50.3 & 50.0 & 112 & Quartz & Hexagonal & $85-0865$ \\
\hline 64.3 & 65.5 & 125 & Hematite & Rhombohedral & $88-2359$ \\
\hline 67.9 & 67.9 & 104 & Aragonite & Orthorhombic & $76-0606$ \\
\hline 68.4 & 68.4 & 242 & Aragonite & Orthorhombic & $76-0606$ \\
\hline 73.6 & 73.1 & 117 & Illite & Monoclinic & $29-1496$ \\
\hline 75.8 & 75.7 & 243 & Aragonite & Orthorhombic & $71-2392$ \\
\hline
\end{tabular}

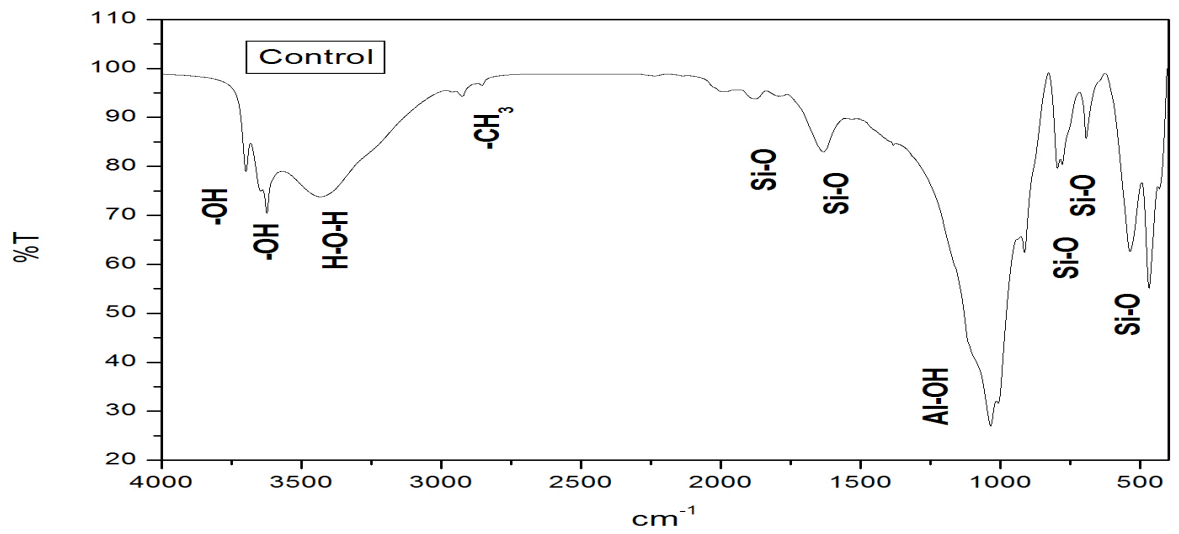

Fig.-4: The FTIR Spectrum of the Control Plot 
RASĀYAN J. Chem.

Vol. 14 | No. 4 |2255-2262| October- December | 2021

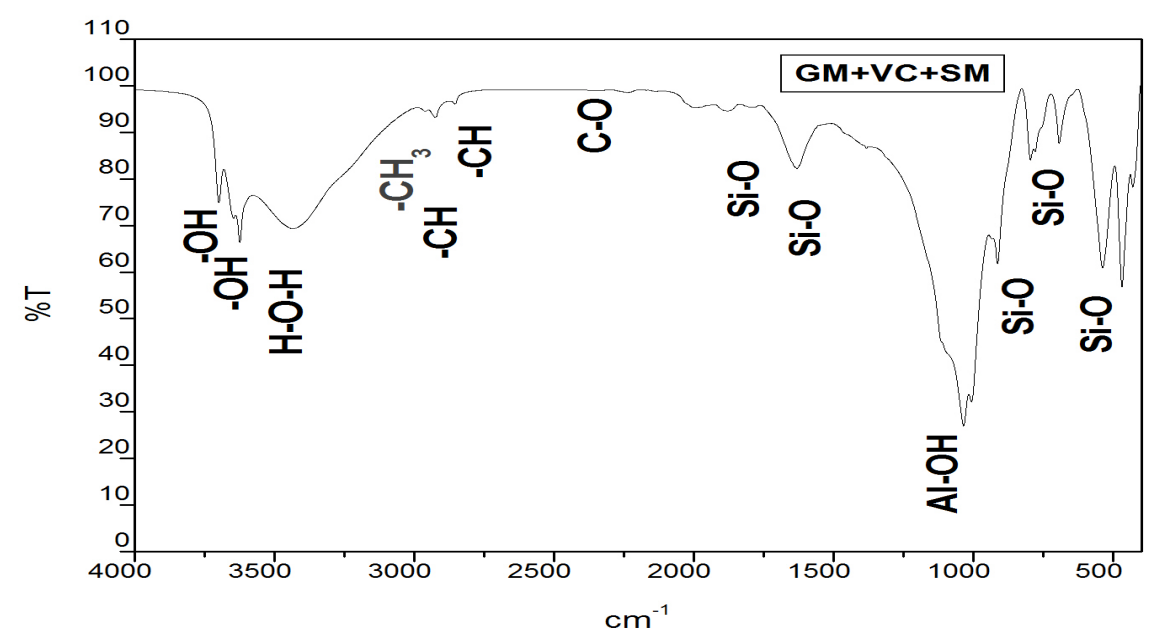

SEM

Fig.-5: The FTIR Spectrum of the G+SM+VC Plot

SEM with EDAX is used to analyze the morphology, structural distribution and chemical composition of soil containing ultrafine debris and minerals. ${ }^{16}$ SEM images of the soil samples shown here are for the control plot and $\mathrm{G}+\mathrm{SM}+\mathrm{VC}$ plot with 5000 magnification at $20 \mathrm{kV}$ are depicted in Fig.-6. It indicates that it has more macrospore in it, which implies that it has low Water Holding Capacity (WHC) and aeration. SEM image of soil treated with organic manure shows more number of microspores. This represents the contents of organic manure entering into the cavity of macrospores and decreases the pore size which ultimately increases the microspores in the soil. Along with this improvement in soil structure, it also increases the WHC of the soil.

\section{EDAX}

Scanning electron microscopy with energy-dispersed X-ray analysis (SEM/EDAX) is commonly used for particle studies that assess microstructural modifications within the treated soil. ${ }^{17} \mathrm{In}$ this present study, the elemental concentration data of soil samples treated without and with organic manures are given in the Table- 3 . The oxygen content is $68 \%$ in untreated soil, but organic manure mixed soil shows $69 \%$ oxygen, which may be due to the porosity changes and accumulation of oxygen in the microspores. Potassium and Magnesium are important basic cations that may influence the cation exchange capacity of the soil and are also responsible for the growth of the plant. Due to the incorporation of organic manure in it has slightly increased the contents of $\mathrm{K}$ and $\mathrm{Mg}$ to the tune of $0.72 \%$ and $1.09 \%$. The contents of elements $\mathrm{Fe}$, $\mathrm{Ca}, \mathrm{Si}$ and $\mathrm{Al}$ was reduced significantly than the untreated soil. Fig.-7 shows the EDAX spectrum of the soil treated without and with organic manures.
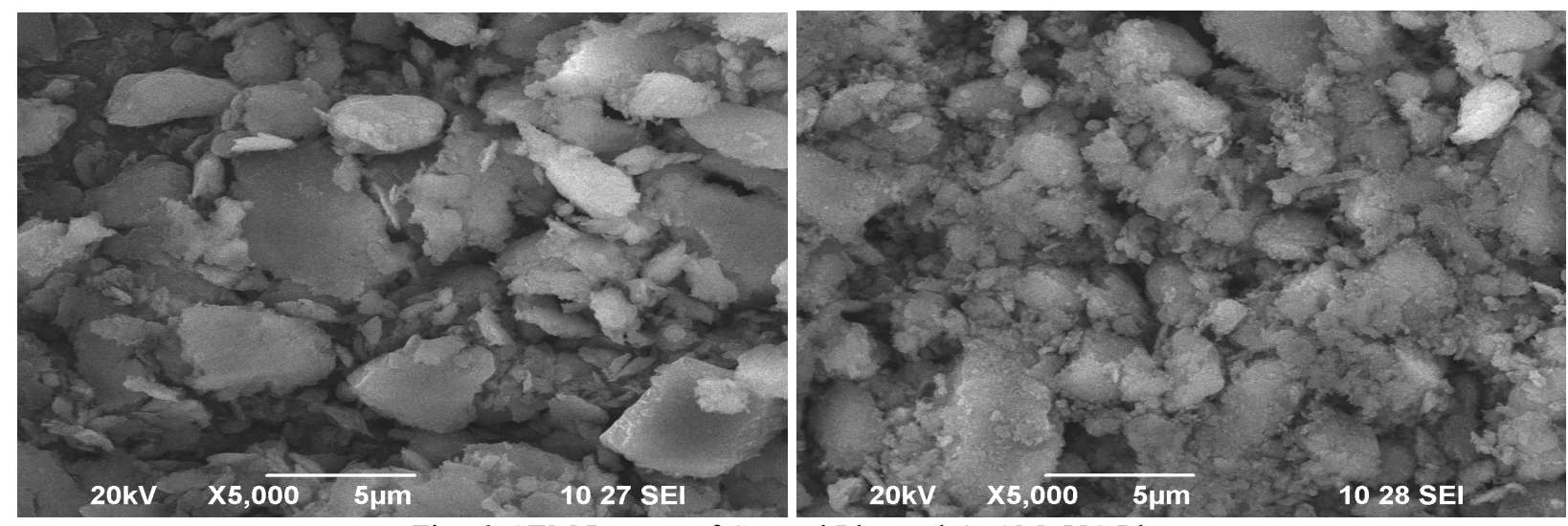

Fig.-6: SEM Images of Control Plot and G+SM+VC Plot 
RASĀYAN J. Chem.

Vol. 14 | No. 4 |2255-2262| October- December | 2021

Table-4: Elemental Composition Data of Control Plot

\begin{tabular}{c|c|c|c}
\hline Element & $\begin{array}{c}\text { Applied } \\
\text { Concentration }\end{array}$ & $\begin{array}{c}\text { Weight } \\
\%\end{array}$ & $\begin{array}{c}\text { Atomic } \\
\%\end{array}$ \\
\hline Oxygen $(\mathrm{O})$ & 35.6 & 54.3 & 68.9 \\
\hline Magnesium $(\mathrm{Mg})$ & 0.4 & 0.9 & 0.7 \\
\hline Aluminium $(\mathrm{Al})$ & 5.9 & 11.0 & 8.2 \\
\hline Silicon $(\mathrm{Si})$ & 13.4 & 26.4 & 19.1 \\
\hline Potassium $(\mathrm{K})$ & 0.6 & 1.0 & 0.5 \\
\hline Calcium $(\mathrm{Ca})$ & 0.6 & 1.0 & 0.5 \\
\hline Iron $(\mathrm{Fe})$ & 2.7 & 5.2 & 1.8 \\
\hline
\end{tabular}

Table-5: Elemental Composition Data of G+VC+SM Plot

\begin{tabular}{c|c|c|c}
\hline Element & $\begin{array}{c}\text { Applied } \\
\text { Concentration }\end{array}$ & $\begin{array}{c}\text { Weight } \\
\%\end{array}$ & $\begin{array}{c}\text { Atomic } \\
\%\end{array}$ \\
\hline Oxygen $(\mathrm{O})$ & 42.0 & 54.4 & 69.0 \\
\hline Magnesium $(\mathrm{Mg})$ & 0.7 & 1.3 & 1.0 \\
\hline Aluminium $(\mathrm{Al})$ & 6.6 & 10.5 & 7.8 \\
\hline Silicon $(\mathrm{Si})$ & 15.7 & 25.9 & 18.7 \\
\hline Chlorine $(\mathrm{Cl})$ & 0.2 & 0.4 & 0.2 \\
\hline Potassium $(\mathrm{K})$ & 1.0 & 1.3 & 0.7 \\
\hline Calcium $(\mathrm{Ca})$ & 0.6 & 0.9 & 0.4 \\
\hline Iron $(\mathrm{Fe})$ & 3.2 & 5.1 & 1.8 \\
\hline
\end{tabular}

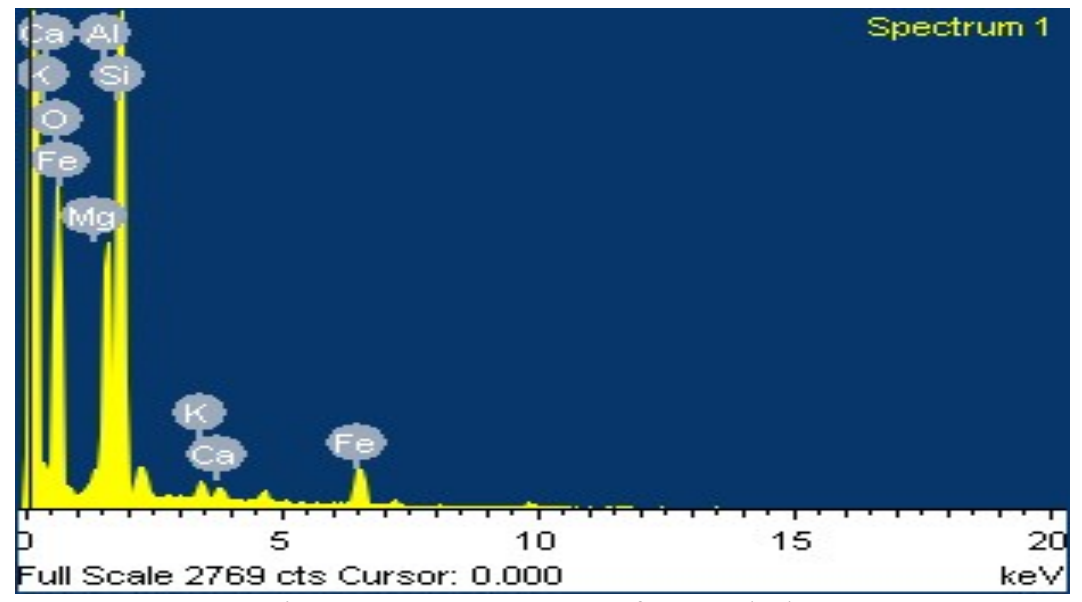

Fig.-7: EDAX Spectrum of Control Plot

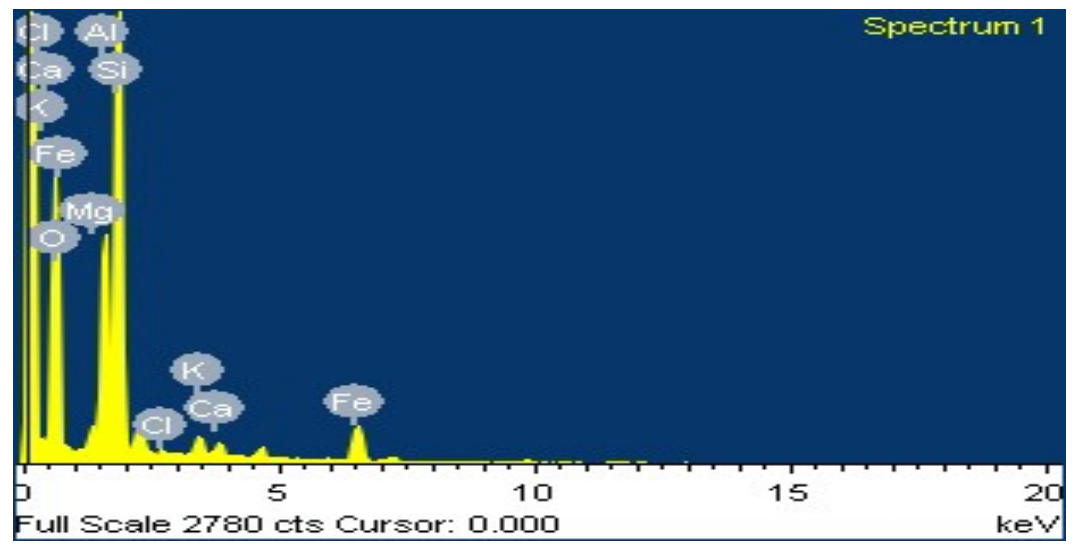

Fig.-8: EDAX Spectrum of G+SM+VC Plot 
RASĀYAN J. Chem.

Vol. 14 | No. 4 |2255-2262 | October- December | 2021

\section{CONCLUSION}

In this present study, it is found out that there is the presence of minerals like quartz, kaolinite, montmorillonite, Illite in untreated soil, which is confirmed with PXRD. After the application of organic manure, there is the presence of organic carbon in addition to the minerals occurring in untreated soil. This has been confirmed through FTIR characterization. The presence of organic carbon confirms the improvement of soil fertility. From the SEM study, it is predicted that microspores present in organic manure mixed soil indicate that the manure has been implemented well into the sample and improved the water holding capacity and soil aeration. The results of EDAX also prove that there is a significant change in the content of micronutrients in the soil after the application of the organic amendment.

\section{ACKNOWLEDGEMENT}

I, R. Suya Padhra Haridha, Research Scholar (18221282132015) am thankful to authorities of Department of Physics, Sarah Tucker College (Autonomous), Tirunelveli, Department of Physics, St.Xavier's College (Autonomous), Palayamkottai and Manonmaniam Sundaranar University, Tirunelveli-12 for providing necessary research facilities.

\section{REFERENCES}

1. V. Gashi, B. Kelmendi, N. Shala, I. Cacaj, O. Gashi, and V. Havolli, Rasayan Journal of Chemistry, 12(3), 1540(2019), https://doi.org/10.31788/RJC.2019.1235301

2. G. Selvakumar, S. Reetha and P.Thamizhiniyan, World Applied Sciences Journal, 16(10), 1368(2016).

3. S. Agyenim Boateng, J. Zickermann, and M. Komahrens, West African Journal of Applied Ecology, 9(1), 1(2006), https://doi.org/10.4314/wajae.v9i1.45682

4. H. Alhrout, N. Bani-Hani, M. A. Haddad, J. A. S. Al-Tabbal, H. K. Aldalin and M. M. Alkharabsheh, Journal of Agronomy, 16(4), 174(2017), https://doi.org/10.3923/ja.2017.174.179

5. P. Jeyaseeli, F. Jeyamangalam, S. Selvaraj and S. C. Vella Durai, Rasayan Journal of Chemistry, 14(1), 74(2021), https://doi.org/10.31788/RJC.2021.1416119

6. F. Jeyamangalam, T. Franciya and Saral Kiruba, Journal of Eco-friendly Agriculture, 11(1), 24(2016).

7. M. A. Adegbite, A. R. Sanda, A. A. Musa, I. B.Ahmed and S. I. Zakari, International Journal of Agriculture and Environmental Research, 4(2), 456(2018).

8. R. Kaur, M. Bansal, S. Sharma, and S. Tallapragada, Rasayan Journal of Chemistry, 12(2), 421(2019), https://doi.org/10.31788/RJC.2019.1225160

9. B. Das and N. K. Mondal, Universal Journal of Environmental Health and Biology, 1, 515(2011).

10. K. M. Satova, Sh. M. Zhumadina, Sh. B. Abilova, N. B. Mapitov and A. K. Jaxylykova, Rasayan Journal of Chemistry, 13(3), 1627(2020), https://doi.org/10.31788/RJC.2020.1335672

11. N. O. A. Cannane, M. Rajendran and R. Selvaraju. Journal of Environmental Nanotechnology, 3(2), 23(2014).

12. A. Laajeb, A. Addaou, A. Lahsini, F. Ghomri, M. Elfatri and M. A. Rodriguez. Asian Journal of Chemistry, 24(11), 485(2012).

13. D. B. Ghale, N. B. Bohara, N. Duwal and J. Bhattarai, Rasayan Journal of Chemistry, 12(2), 402(2019), https://doi.org/10.31788/RJC.2019.1224034

14. S. Zhao, G. Liu, Q. Ou, X. Zhao, J. Ren, J. Xu and J. Hao, Asian Journal of Chemistry, 26(22), 7581(2014), https://doi.org/10.14233/ajchem.2014.16889

15. S. A. Bhat, J. Singh and A. P. Vig. Journal of Analytical Science and Technology, 8(2), 2(2017), https://doi.org/10.1186/s40543-017-0112-2

16. A.U. Bappa, and A. Haruna, Journal of applied sciences and environmental management, 19(3), 403(2015), https://doi.org/10.4314/jasem.v19i3.9

17. Z. Shi, L. Shao, T. P. Jones, A. G. Whittaker, S. Lu, K. A. Berube, T. He, and R. J. Richards, Atmospheric Environment, 37(29):4097(2003), https://doi.org/10.1016/S1352-2310(03)00531-4

[RJC-6515/2021]

ORGANICALLY AMENDED SOIL 